DOI: $10.1515 / \mathrm{rrlm}-2015-0044$

\title{
PCR coupled with mass-spectrometry for detection of Clostridium difficile virulence markers during the emergence of ribotype 027 in Bucharest area
}

\author{
PCR cuplat cu spectrometria de masă pentru detecţia markerilor de \\ virulenţă ai Clostridium difficile în cursul emergenţei ribotipului 027 în \\ Bucureşti
}

\author{
Dragos Florea ${ }^{1,3}$, Steliana Huhulescu ${ }^{2}$, Alexander Indra ${ }^{2}$, Ioana Badicut ${ }^{1}$, \\ Alexandru Rafila ${ }^{1,3}$, Dan Otelea ${ }^{1}$, Gabriel Adrian Popescu ${ }^{1,3}$ \\ 1. National Institute for Infectious Diseases "Prof Dr Matei Bals", Bucharest, Romania; 2. Austrian \\ Agency for Health and Food Safety (AGES) Vienna, Austria; 3. University of Medicine and Pharmacy \\ "Carol Davila", Bucharest, Romania
}

\begin{abstract}
In recent years Clostridium difficile infection (CDI) has represented a serious public health issue, mainly due to the global spread of the hypervirulent strain NAP1/027/BI. The purpose of the present study was to evaluate the utility of a PCR coupled with electrospray ionization mass spectrometry (ESI-MS) commercial assay for the detection of $C$. difficile virulence markers. Non-duplicative $C$. difficile isolates from patients with CDI diagnosed in a tertiary level hospital from Bucharest were tested for toxin A, toxin B, binary toxin genes and deletion in tcdC gene using PCR/capillary gel electrophoresis and PCR/ESI-MS. The study analysed 45 non-duplicative isolates, 33 strains (73.3\%) belonging to ribotype 027. The concordance between PCR/capillary gel electrophoresis and PCR/ ESI-MS was 100\% for toxin A gene, 97.8\% for toxin B gene, 91.1\% for binary toxin subunit A gene and $95.6 \%$ for binary toxin subunit B gene. The general concordance for the complete panel of markers was $88.9 \%$ but was $100 \%$ for ribotype 027 isolates. PCR/ESI-MS might be a valid method for the detection of $C$. difficile virulence markers, including binary toxin.

Keywords: Clostridium difficile, ribotype 027, binary toxin, deletion in tcdC gene, electrospray ionization mass spectrometry

\section{Rezumat}

Infecţia cu Clostridium difficile (ICD) a devenit în ultimii ani o importantă problemă de sănătate publică, în special datorită diseminării globale a tulpinii hipervirulente NAP1/027/BI. Obiectivul studiului nostru a fost de a evalua utilitatea unui test comercial care utilizează PCR cuplat cu spectrometria de masă cu ionizare prin
\end{abstract}

*Corresponding author: Dragoș Florea, National Institute for Infectious Diseases, Bucharest, Romania, e-mail: dragos.florea@yahoo.com 
electrospray (PCR/ESI-MS) pentru detecţia markerilor de virulenţă ai C. difficile. Genele care codifică toxina A, toxina B, toxina binară, precum şi deleția în gena tcdC au fost detectate prin PCR/ electroforeză în gel capilar, respectiv PCR/ESI-MS pentru tulpini de C. difficile izolate de la pacienţi diagnosticaţi cu ICD intr-un spital de nivel terţiar din Bucureşti. Studiul a analizat 45 de izolate, 33 dintre acestea $(73,3 \%)$ fiind ribotip 027. Concordanţa dintre PCR/electroforeza în gel capilar şi PCR/ESI-MS a fost de 100\% pentru gena toxinei A, 97,8\% pentru gena toxinei $B, 91,1 \%$ pentru gena subunităţii A a toxinei binare şi 95,6\% pentru gena subunităţii $B$ a toxinei binare. Pentru întreg setul de markeri concordanţa dintre cele două metode a fost constatată la $88,9 \%$ din totalul tulpinilor şi a fost completă pentru izolatele ribotip 027. PCR/ESI-MS ar putea fi o metodă utilă pentru detecţia markerilor de virulenţă ai C. difficile.

Cuvinte cheie: Clostridium difficile, ribotip 027, toxina binară, deleţie în gena tcdC, spectrometrie de masă

Received: $21^{\text {st }}$ August 2015; Accepted: 25 th October 2015; Published: $25^{\text {th }}$ November 2015

\section{Introduction}

Clostridium difficile infection (CDI) is the major cause of healthcare associated diarrhoea [1]. The pathogenic mechanism is toxigenic, the virulence factors being enterotoxin $\mathrm{A}$ and cytotoxin B. In the last years CDI has shown increased incidence and severity, becoming a serious public health issue in countries with a large consumption of broad spectrum antimicrobials, especially fluoroquinolones, $2^{\text {nd }}$ to $4^{\text {th }}$ generation cephalosporins and carbapenems [13]. This change in CDI epidemiology was the result of the global spread of the hypervirulent strain NAP1/027/BI, derived from a classical ribotype 027 after fluoroquinolones resistance acquisition; Stadler et al. identified at least five genetic region changes in ribotype 027 compared with isolates from 1984 [4]. The higher epidemic risk of the hypervirulent ribotype 027 seems to be the result of an increased production of toxins A and B, the synthesis of a supplemental binary toxin, and a higher capacity of spore production [2].

Accurate diagnosis of CDI is needed both for patient management and initiation of adequate infection control measures. A long-lasting CDI epidemic in a medical facility and the detection of binary toxin positive isolates strongly suggest the involvement of $C$. difficile ribotype 027, since other $C$. difficile binary toxin-positive ribotypes, like 078 or 244 , are much less frequently involved in human disease [3, 5]. In the first months of 2011 the number of CDI cases in Bucharest increased sharply. Although C. difficile ribotyping was not performed at that moment, the strains were collected and tested several months later in reference laboratories from Leiden, Netherlands and Vienna, Austria, thus confirming the change in the epidemiology of CDI and the increased proportion of ribotype 027 in Romania [6].

The purpose of the present study was to evaluate the utility of a commercial assay using PCR coupled with electrospray ionization mass spectrometry (ESI-MS) for the detection of Clostridium difficile virulence markers in isolates from patients with CDI.

\section{Methods}

\section{Bacterial isolates}

The study analyzed 45 non-duplicative isolates of Clostridium difficile from patients with CDI admitted from July to December 2011 in the National Institute for Infectious Diseases (NIID), a tertiary level hospital from Bucharest, Romania. Forty-three patients with a clinical suspicion of CDI were transferred to NIID from several hospitals located in the Bucharest area; the other two patients were documented hospital associated cases, being diagnosed shortly after a previous NIID hospitalization. An informed consent was obtained from each patient. 
All 45 isolates were stored at $-80{ }^{\circ} \mathrm{C}$ in cryobank tubes until DNA testing and were subcultured on Columbia blood agar plates (bioMérieux, Marcy l'Etoile, France) before testing.

\section{Reference methods for identification of $C$. difficile virulence markers}

All 45 isolates were tested in June 2012 at the Austrian Reference Centre for Clostridium difficile (AGES, Vienna, Austria). A previously described protocol using PCR/ capillary gel electrophoresis was used for PCR ribotyping (RT) [7]. A PCR based toxin typing was performed, as previously described, for toxin A [8], toxin B [9, 10] and $t c d C$ deletion [12]. These results were considered as reference.

\section{PCR/ESI-MS protocol for C. difficile}

All 45 isolates were tested in August 2012 at the National Institute for Infectious Diseases (NIID), Bucharest, Romania. Nucleic acid extraction from isolate suspension was performed on the EasyMag instrument (Biomerieux, Marcy l'Etoile, France) using the specific B protocol, according with the manufacturer's recommendations, the extracted DNA being eluted in a $40 \mu \mathrm{l}$ volume of elution buffer.

For polymerase chain reaction (PCR) and subsequent mass spectrometry we used the $C$. difficile Typing and Virulence Assay (Abbott Molecular, Des Plains, USA). This commercial assay is based on eight PCR reactions performed simultaneously, with the following protocol: initial denaturation $95^{\circ} \mathrm{C}, 10$ minutes, then 8 cycles of $95^{\circ} \mathrm{C}$ for 30 seconds, $48^{\circ} \mathrm{C}$ for 30 seconds, $72^{\circ} \mathrm{C}$ for 30 seconds, followed by 37 cycles of $95^{\circ} \mathrm{C}$ for 15 seconds, $56^{\circ} \mathrm{C}$ for 20 seconds, $72^{\circ} \mathrm{C}$ for 20 seconds, and a final step of $72^{\circ} \mathrm{C}$ for 2 minutes, $99^{\circ} \mathrm{C}$ for 20 minutes. Two primer pairs target regions of tpi (triosephosphate isomerase gene), allowing Clostridium species identification, and other four primer pairs target genes encoding $C$. difficile virulence factors: binary toxin alpha and beta subunits ( $c d t A$ and $c d t B$, respectively), enterotoxin $\mathrm{A}(t c d A)$ and cytotoxin $\mathrm{B}$ $(t c d B)$. The assay describes two polymorphism variants of the $t c d B$ gene: wild type and mutant. The last two PCR reactions are designed to detect deletions in the $t c d C$ gene: a single base pair deletion at position 117 , responsible for a frameshift that create a stop codon at position 196 [13] or other deletions [14].

PCR products were analyzed by electrospray ionization - time of flight mass spectrometry using the PLEX-ID analyzer (Abbott Molecular, Des Plaines, IL, USA). This instrument automatically measures the molecular weight of each PCR product, calculates the base composition of the products and compares these data with information from an internal database, using an integrated software.

\section{Results}

\section{Characterization of $C$. difficile isolates using PCR/CGE}

All but one of the $45 C$. difficile isolates produced toxins. Following PCR RT 433 an isolate was found to lack the genes for toxin A, toxin B and binary toxin. All 44 toxigenic strains harboured toxin A and toxin B and 33 (75\%) of these isolates were also positive for both binary toxin genes.

Ribotype 027 was the dominant ribotype, accounting for $33(75 \%)$ of the 44 toxigenic strains. The remaining 12 isolates were ribotype $018(n=6), 012(n=2)$, and one isolate each of: 081, 433, 500 and PR03055 (new ribotype). The distribution of ribotypes among the 45 isolates and the characterization of the virulence factors of these isolates are presented in table I.

Characterisation of the 45 C. difficile isolates using PCR/ESI-MS

All but one of the 45 isolates tested with PCR / ESI-MS were $t c d A$ and $t c d B$ positive; one iso- 
Table I. Distribution of $\mathrm{C}$ difficile rybotype and virulence markers genes for $\mathbf{4 5}$ isolates tested with PCR/CGE

\begin{tabular}{ccccccc}
\hline $\begin{array}{c}\text { Number of } \\
\text { cases }\end{array}$ & $c d t A$ & $c d t B$ & $t c d A$ & $t c d B$ & $\begin{array}{c}t c d C \text { geno- } \\
\text { type }\end{array}$ & Ribotype \\
\hline 1 & + & + & + & + & 140 & 027 \\
\hline 30 & + & + & + & + & 141 & 027 \\
\hline 1 & + & + & + & + & 142 & 027 \\
\hline 1 & + & + & + & + & 143 & 027 \\
\hline 10 & - & - & + & + & 160 & $012,018,081,500$ \\
\hline 1 & - & - & + & + & 162 & PRO3035 \\
\hline 1 & - & - & - & - & 160 & 433 \\
\hline
\end{tabular}

$\overline{t c d A}=$ enterotoxin $\mathrm{A}$ gene, $t c d B=$ cytotoxin $\mathrm{B}$ gene; $c d t A=$ binary toxin alpha subunit gene; $c d t B$ = binary toxin beta subunit gene; $t c d C=$ putative negative regulator of the production of toxin $\mathrm{A}$ and $\mathrm{B}$; PRO3035 = new ribotype.

late of PCR-RT 433 was identified as only $t c d B$ positive. The binary toxin coding genes, $c d t A$ and $c d t B$, were detected in 35 isolates: 33 of them belonged to RT 027 and two of them belonged to RT 018 and 500. In other two isolates of RT 012 and PRO3035, the assay detected only the $c d t A$ gene; these 37 possible producing binary toxin isolates represent $82.2 \%$ of the $C$. difficile strains, CI95\% (68.7\%; 90.7\%). In 34 of these 37 cases (91.9\%) this method identified also an $18 \mathrm{bp}$ and respectively 117 bp $t c d C$ deletion (table II). All isolates with $t c d C$ deletions had the tcdB variant and only one of the other 11 isolates had this tcdB variant: $100 \%$ versus $9.1 \%, \mathrm{p}<0.00001$.

In all but five isolates the PCR/ ESI-MS showed similar virulence marker profiles compared to the reference methods, with an overall complete concordance of $88.9 \%$ (CI95\% 76.5\%$95.2 \%)$. The concordance was good for each of the virulence markers: $100 \%$ (CI 95\% 92.1$100 \%$ ) for toxin A gene, 97.8\% (CI95\% 88.499.6\%) for toxin B gene, 91.1\% (CI 95\% 79.3 96.5) for binary toxin subunit A gene and 95.6\% (CI 95\% 85.2 - 98.8) for binary toxin subunit B gene (table III). In ribotype 027 strains this concordance was $100 \%$ for each marker.

In four strains, belonging to ribotypes 012 , 018, 500 and PRO3055, the binary toxin subunit A gene was detected with PCR/ESI-MS only.

The association between the binary toxin and the 18 bp deletion in $t c d C$ gene, detected with PCR/ESI-MS, identified ribotype 027 strains with a positive predictive value of $91.6 \%$ and a negative predictive value of $100 \%$.

Table II. Distribution of C difficile virulence markers for 45 isolates tested with PCR/ESI-MS

\begin{tabular}{cccccccr}
\hline $\begin{array}{c}\text { Number of } \\
\text { cases }\end{array}$ & $c d t A$ & $c d t B$ & $t c d A$ & $t c d B$ & $\begin{array}{c}t c d C \\
18 \text { bp del }\end{array}$ & $\begin{array}{c}t c d C \\
117\end{array}$ & Ribotype \\
\hline 34 & + & + & + & $\mathrm{m}$ & + & + & 027,500 \\
\hline 1 & + & + & + & $\mathrm{wt}$ & - & - & 018 \\
\hline 2 & + & - & + & $\mathrm{wt}$ & - & - & $012,018,081$ \\
\hline 7 & - & - & + & $\mathrm{wt}$ & - & - & 433 \\
\hline 1 & - & - & - & $\mathrm{m}$ & - & - & 03035 \\
\hline
\end{tabular}

$\overline{t c d A}=$ enterotoxin $\mathrm{A}$ gene, $t c d B=$ cytotoxin $\mathrm{B}$ gene; $c d t A=$ binary toxin alpha subunit gene; $c d t B$ = binary toxin beta subunit gene; $t c d C=$ putative negative regulator of the production of toxin A and B; PRO3035 = new RT.

wt-wild type $\mathrm{m}$ - mutant 
Table III. Concordance between PCR/ESI-MS and PCR/capillary gel electrophoresis for 45 C. difficile isolates

\begin{tabular}{|c|c|c|c|c|}
\hline $\begin{array}{c}\text { Ribotype } \\
\text { (number of cases) }\end{array}$ & Gene & PCR/CGE & PCR/ESI-MS & $\begin{array}{c}\text { Concordance \% } \\
\text { (CI95) }\end{array}$ \\
\hline \multirow{5}{*}{$\begin{array}{c}027 \\
(\mathrm{n}=33)\end{array}$} & $c d t A$ pos & 33 & 33 & $100(89.6-100)$ \\
\hline & $c d t B$ pos & 33 & 33 & $100(89.6-100)$ \\
\hline & $t c d A$ pos & 33 & 33 & $100(89.6-100)$ \\
\hline & $t c d B$ pos & 33 & 33 & $100(89.6-100)$ \\
\hline & $t c d C$ del & 33 & 33 & $100(89.6-100)$ \\
\hline \multirow{5}{*}{$\begin{array}{l}\text { Non-027 } \\
(\mathrm{n}=12)\end{array}$} & $c d t A$ pos & 0 & 4 & $66.7(34.9-90.1)$ \\
\hline & $c d t B$ pos & 0 & 2 & $83.3(51.6-97.9)$ \\
\hline & $t c d A$ pos & 11 & 11 & $100(71.5-100)$ \\
\hline & $t c d B$ pos & 11 & 12 & $91.7(61.5-99.8)$ \\
\hline & $t c d C$ del & 0 & 0 & N.A. \\
\hline \multirow{5}{*}{$\begin{array}{c}\text { All } \\
(n=45)\end{array}$} & $c d t A$ pos & 45 & 41 & $91.1(79.3-96.5)$ \\
\hline & $c d t B$ pos & 45 & 43 & $95.6(85.2-98.8)$ \\
\hline & $t c d A$ pos & 45 & 45 & $100(92.1-100)$ \\
\hline & $t c d B$ pos & 44 & 45 & $97.8(88.4-99.6)$ \\
\hline & $t c d C$ del & 33 & 33 & $100(89.6-100)$ \\
\hline
\end{tabular}

$\overline{t c d A}=$ enterotoxin $\mathrm{A}$ gene, $t c d B=$ cytotoxin $\mathrm{B}$ gene; $c d t A=$ binary toxin alpha subunit gene; $c d t B$ = binary toxin beta subunit gene; $t c d C=$ putative negative regulator of the production of toxin $\mathrm{A}$ and $\mathrm{B}$; del = deletion

\section{Discussions}

Broad-range PCR coupled with electrospray ionization mass-spectrometry was developed both for clinical diagnosis and epidemiological surveillance, being able to provide a rapid identification of multiple bacterial, fungal and viral pathogens from clinical samples during outbreaks $[15,16]$. The present study showed that PCR/ESI-MS might be a valid method for $C$. difficile identification and detection of virulence markers, with a valuable role for the identification of emerging hypervirulent strains. However, other aspects, like costs and complexity of the equipment, may impact the clinical utility of this method. At this stage it is difficult to perform a clinical cost-benefit analysis since PCR-ESIMS and PCR-CGE are research techniques used mainly for epidemiological purposes, with costs that vary from one setting to another.
The recent emergence of CDI with ribotype 027 was described in several areas where infection control procedures failed to contain the spread of this ribotype. In contrast, countries with sustained and efficient infection control interventions were able to reduce the prevalence of ribotype 027 infections. United Kingdom is an example of such successful actions, resulting in a decrease of ribotype 027 prevalence from 55\% to $21 \%$ in five years [17]. In Bucharest area the high proportion of CDI with ribotype 027 was first suggested by the sharp increase of incidence and severity of CDI admitted in NIID starting with 2011: a seven fold increase of CDI cases in 2011 compared to the previous year and a 10\% lethality compared with no fatalities in 2010 [6].

The dominance of ribotype 027 strains described in the present study is most probably not the result of a single hospital outbreak, because 
the patients admitted in NIID, an infectious diseases tertiary level hospital, were transferred from virtually all other hospitals in Bucharest and the surrounding area. The detection of ribotype 027 described in the present study is very high compared to data from other countries and is probably related to the state of epidemic CDI in this region. Other studies revealed that $027 \mathrm{re}-$ mained during the following years the dominant ribotype in Bucharest and in many other Romanian regions [18].

In one isolate (RT 433) only toxin B gene was detected, the gene for toxin A being undetectable. The result for toxin B gene was not confirmed by the reference method. Although the virulence of toxA-toxB $+C$. difficile strains was not fully accepted, more recent data confirm their involvement in CDI pathogenesis, some studies suggesting an even higher virulence compared to the tox $\mathrm{A}+$ toxB + strains [19]. This particular toxigenic $C$. difficile is present in variable proportions in different statistics and is not correlated with a specific ribotype.

A limitation of our study was the small number of isolates analyzed, mainly for non027 ribotypes. Although unexpectedly high, the increased prevalence of the 027 strains in the present study is concordant with the prevalence described in a larger study performed in 11 Romanian hospitals [18] and therefore is not likely to be considered, in our opinion, the result of sampling bias.

\section{Conclusions}

The present study demonstrated that PCR coupled with ESI-MS might be a valid method for detection of $C$. difficile virulence markers. The characteristics of the isolates tested with this method confirm the emergence of $C$. difficile ribotype 027 in Bucharest area in 2011.

\section{Acknowledgements}

DF has been funded by grant POSDRU /159/1.5/S/135760. CERO.

The data were partially presented at the $23 \mathrm{rd}$ European Congress of Clinical Microbiology and Infectious Diseases, Berlin, April 2013 (Florea $D$, Huhulescu $S$, Indra $A$, Badicut I, Rafila A, Otelea D, Popescu GA. PCR coupled with mass-spectrometry for detection of Clostridium difficile virulence markers. Poster no. 1864)

\section{References}

1. Bauer MP, Notermans DW, van Benthem BH, Brazier JS, Wilcox MH, Rupnik M, et al. Clostridium difficile infection in Europe: a hospital-based survey. Lancet. 2011;377:63-73. DOI: 10.1016/S0140-6736(10)612664

2. Vohra P, Poxton IR. Comparison of toxin and spore production in clinically relevant strains of Clostridium difficile. Microbiology. 2011;157:1343-53. DOI: 10.1099/ mic.0.046243-0

3. Goorhuis A, Bakker D, Corver J, Debast SB, Harmanus C, Notermans DW, et al. Emergence of Clostridium difficile infection due to a new hypervirulent strain, polymerase chain reaction ribotype 078. Clin Infect Dis. 2008;47:1162-70. DOI: 10.1086/592257

4. Stabler RA, He M, Dawson LFT, Martin M, Valiente E, Parkhill J, et al Comparative genome and phenotypic analysis of Clostridium difficile 027 strains provides insight into the evolution of a hypervirulent bacterium. Genome Biol. 2009;10:R102. DOI: 10.1186/gb-200910-9-r102

5. Lim SK, Stuart RL, Mackin KE, Carter GP, Kotsanas D, Francis MJ, et al. Emergence of a ribotype 244 strain of Clostridium difficile associated with severe disease and related to the epidemic ribotype 027 strain. Clin Infect Dis. 2014;58:1723-30. DOI: 10.1093/cid/ciu203

6. Rafila A, Indra A, Popescu GA, Wewalka G, Allerberger F, Benea S, et al. Occurrence of Clostridium difficile infections due to PCR ribotype 027 in Bucharest, Romania. J Infect Dev Ctries. 2014;8:694-8. DOI: $10.3855 /$ jidc. 4435 
7. Indra A, Huhulescu S, Schneeweis M, Hasenberger P, Kernbichler S, Fiedler A, et al. Characterization of Clostridium difficile isolates using capillary gel electrophoresis -based PCR ribotyping. J Med Microbiol. 2008;57:1377-82. DOI: 10.1099/jmm.0.47714-0

8. van den Berg RJ, Claas ECJ, Oyib DH, Klaassen CHW, Dijkshoorn L, Brazier JS, et al. Characterization of toxin A-negative, toxin B-positive Clostridium difficile isolates from outbreaks in different countries by amplified fragment length polymorphism and PCR ribotyping. J Clin Microbiol. 2004;42:1035-41. DOI: 10.1128/ JCM.42.3.1035-1041.2004

9. Kato N, Ou CY, Kato H, Bartley SL, Brown VK, Dowell VRJ, Jr, et al. Identification of toxigenic Clostridium difficile by the polymerase chain reaction. J Clin Microbiol. 1991;29:33-7.

10. Kato H, Kato N, Katow S, Maegawa T, Nakamura S, Lyerly DM. Deletions in the repeating sequences of the toxin A gene of toxin A-negative, toxin B-positive Clostridium difficile strains. FEMS Microbiol Lett. 1999;175:197-203. DOI: 10.1111/j.1574-6968.1999. tb13620.x

11. Stubbs SL, Brazier JS, Talbot PR, Duerden BI. PCR-restriction fragment length polymorphism analysis for identification of Bacteroides spp. and characterization of nitroimidazole resistance genes. J Clin Microbiol. 2000;38:3209-13.

12. Spigaglia P, Mastrantonio P. Molecular analysis of the pathogenicity locus and polymorphism in the putative negative regulator of toxin production (TcdC) among Clostridium difficile clinical isolates. J Clin Microbiol. 2002;40:3470-5. DOI: 10.1128/JCM.40.9.34703475.2002

13. Curry SR, Marsh JW, Muto CA, O’Leary MM, Pas- culle AW, Harrison LH. tcdC Genotypes associated with severe tcdC truncation in an epidemic clone and other strains of Clostridium difficile. J Clin Microbiol. 2007;45:215-21. DOI: 10.1128/JCM.01599-06

14. Wolff D, Brüning T, Gerritzen A. Rapid detection of the Clostridium difficile ribotype $027 \mathrm{tcdC}$ gene frame shift mutation at position 117 by real-time PCR and melt curve analysis. Eur J Clin Microbiol Infect Dis. 2009;28:959-62. DOI: 10.1007/s10096-009-0731-7

15. Ecker DJ, Sampath R, Blyn LB, Eshoo MW, Ivy C, Ecker JA, et al. Rapid identification and strain-typing of respiratory pathogens for epidemic surveillance. Proc Natl Acad Sci U S A. 2005;102:8012-7. DOI: 10.1073/ pnas.0409920102

16. Wolk DM, Kaleta EJ, Wysocki VH. PCR-electrospray ionization mass spectrometry: the potential to change infectious disease diagnostics in clinical and public health laboratories. J Mol Diagn. 2012;14:295-304. DOI: 10.1016/j.jmoldx.2012.02.005

17. Wilcox MH, Shetty N, Fawley WN, Shemko M, Coen $\mathrm{P}$, Birtles A, et al. Changing epidemiology of Clostridium difficile infection following the introduction of a national ribotyping-based surveillance scheme in England. Clin Infect Dis. 2012;55:1056-63. DOI: 10.1093/ $\mathrm{cid} / \mathrm{cis} 614$

18. Popescu G, Serban R, Pistol A, Niculcea A, Preda A, Lemeni D, et al. Clinical and microbiological characterization of Clostridium difficile infection in Romania (2013-2014); a hospital-based study, BMC Infect Dis. 2014;14(Suppl 7):O24. DOI: 10.1186/1471-2334-14$\mathrm{S} 7-\mathrm{O} 24$

19. Drudy D, Fanning S, Kyne L. Toxin A-negative, toxin B-positive Clostridium difficile. Int J Infect Dis. 2007;11:5-10. DOI: 10.1016/j.ijid.2006.04.003 
